\title{
Uterine Ligament Papillary Cystadenoma Associated with von Hippel-Lindau Disease
}

National Cancer Institute

\section{Source}

National Cancer Institute. Uterine Ligament Papillary Cystadenoma Associated with von

Hippel-Lindau Disease. NCI Thesaurus. Code C40142.

A benign mesonephric neoplasm that arises from the uterine ligament and occurs in women with von $\mathrm{Hippel-Lindau} \mathrm{disease.} \mathrm{It} \mathrm{is} \mathrm{a} \mathrm{cystic} \mathrm{lesion} \mathrm{characterized} \mathrm{by} \mathrm{the} \mathrm{presence}$ of multiple papillary excrescences. 